\title{
"LITTLE BETTER THAN CANNIBALS": SIR JOHN DAVIES AND EDMUND BURKE ON PROPERTY AND PROGRESS
}

\author{
Seán Patrick Donlan, Junior Lecturer, School of Law, \\ University of Limerick
}

Their lives separated by a century, any tie joining Sir John Davies (15691626), the most important jurist in early seventeenth-century Ireland, and Edmund Burke (1729-1797) is less than obvious. At the core of the discussion here is a curious historical irony. Elements of Brehon law deemed by Davies, with many other English commentators, to be prohibitive of social and economic progress in Ireland were to reappear less than a century later in the penal laws. This is, of course, entirely consistent. If native custom was seen to effectively obstruct "improvement", it is not surprising that similar formulae would reappear in a legal order designed to inhibit development or to erode the position of propertied catholics. While, in general, Davies and Burke appear to adopt broadly similar schemes of property and progress, in which law and commerce were important influences on manners (broadly understood to include social practices and mores), there were also critical differences. These relate primarily to Burke's substantially different interpretation of Irish history both before and after Davies' time in Ireland. Living as he did on the march-lands of Irish/British, catholic/protestant, even perhaps ancient/modern, identities, Burke provides an especially interesting subject for the student of Irish history. This essay is a first, tentative step in understanding his complex relationship to Ireland and its past. ${ }^{1}$

\section{Little Better Than Cannibals}

The defeat and subsequent submission of Hugh O'Neill, the earl of Tyrone, in the Nine Years War (1594-1603), marked the end of the last major resistance of Gaelic Ireland. Coupled with the "flight of the earls" (1607) and the unsuccessful revolt of Sir Cahir O'Doherty (1608), it made manageable an extensive programme of plantation and colonisation in Ulster. $^{2}$ With the elimination of a Scottish threat by the accession of James I (VI ${ }^{\text {th }}$ of Scotland) to the English crown, England gained effective political

\footnotetext{
1 This article was originally presented as a paper at Louis Cullen's Trinity College seminar series. I remain grateful to Professor Cullen for the invitation. I am indebted, too, to the Irish Legal History Society for a bursary enabling me to visit the Burke archives, from which I have drawn, and to Niall Osborough and Bernadette Cunningham who read drafts of this article.

2 See generally Aiden Clarke with R. Dudley Edwards, "Pacification, plantation, and the catholic question, 1603-23" in TW Mood, FX Martin, FJ Byrne, A new history of Ireland (1976), iii.187-232. On the flight, see especially John McCavitt, "The flight of the earls, 1607", Irish Historical Studies 29 (1994) 159. See also FW Harris, "The rebellion of Sir Cahir O'Doherty and its legal aftermath", Irish Jurist (n s) 15 (1980) 298 and "Matters relating to the indictments of "the fugitive earls" and their principal adherents", Irish Jurist (n s) 18 (1983) 344.
} 
control it had never previously enjoyed, or at least long maintained. ${ }^{3}$ This practical control also permitted, and was secured by, subsequent legal changes that saw the virtual elimination of native Brehon laws throughout Ireland in favour of the application of English common law. Sir John Davies was to play an especially important role in promoting this change. ${ }^{4}$

An Englishman of Welsh parentage, Davies combined significant talents in both poetry and politics. ${ }^{5}$ His political successes, in England as a member of parliament and later in Ireland, were, in fact, aided by poems dedicated to influential patrons and royals. Through this combination of flattery and ability, he was eventually knighted (1603) and obtained, in turn, the posts of Irish solicitor-general (1603-6) and Irish attorney-general (1606-19). Davies was also the first MP for Fermanagh (1613) and leader of the protestant, official group in the Irish parliament, installed as its speaker in a comical scene in which he was physically placed on the lap of an opposition candidate. During this time, Davies was also an English serjeant-at-law and later prime serjeant. Once back in England, he returned to the Westminister parliament, but died the night before he was to become chief justice of king's bench.

Unlike many critics of Irish policy and polity, Davies effected real change in Ireland. His fortuitous arrival at the close of the Nine Years' War permitted him the opportunity to put English law into practical effect in much of the country for the first time. He did so through active manipulation of legal doctrine and management of the courts. ${ }^{6}$ His writings, which perhaps exaggerate his role, were written after nearly a decade in Ireland and document and defend those changes. Dedicated to the king, the Discovery of the true causes why Ireland was never entirely subdued [and] brought under obedience of the crown of England until the beginning of his Majesty's happy reign (1612) explains how, after centuries of mismanagement and diversion, James had finally made an effective conquest. ${ }^{7}$ Relying heavily on the work of Sir Patrick Finglass and William Camden, his fellows in the Society of Antiquities, Davies also dealt at length with the tendency of the "Old English" to adopt Irish manners. A second work, the Report of cases

3 See C Litton Falkner, "Sir John Davis" in Essays relating to Ireland: biographical, historical and topographical (1909), 39-46. The success, too, of protestantism in Scotland had the effect of dividing the Irish and Scots Gaelic cultures. See Stephen G Ellis, "The collapse of the Gaelic world, 1450-1650", Irish Historical Studies 31 (1998-9) 449

4 Cf John McCavitt, “'Good planets in their several spheres'-the establishment of the assize circuits in early seventeenth-century Ireland", Irish Jurist (n s) 24 (1989) 248.

5 See "John Davies" in Leslie Stephen and Sidney Lee (eds), The dictionary of national biography (Oxford, 1917) and Geoffrey Hand, "Sir John Davies", Gazette of the Incorporated Law Society of Ireland 64 (1971) 174.

6 See Ciarán Brady, "The road to the View: on the decline of reform thought in Tudor Ireland" in Patricia Coughlan (ed), Spenser and Ireland: an interdisciplinary perspective (Cork, 1983), 43-4.

7 For a recent reprint see, Davies, A discovery of the true causes why Ireland was never entirely subdued [and] brought under obedience of the crown of England until the beginning of his Majesty's happy reign (Washington, 1969), James $\mathrm{P}$ Myers, Jr (ed). See also Myers' interesting "Early English colonial experiences in Ireland: Captain Thomas Lee and Sir John Davies", Eire-Ireland 23 (1988) 8. 
and matters in law (1615), was a collection of legal-political opinions, documenting the changes effected in the jurisprudence of the Irish courts. ${ }^{8}$ By emphasising the "perfect conquest" following the Nine Years' War, Davies underscored the practical control of the country and concomitant imposition of the common law. He expresses this as a positive development, maintaining that native traditions were prejudicial to the native Irish in a way that English common law was not. ${ }^{9}$ Irish law, like its manners, kept Ireland a nation of "cannibals". ${ }^{10}$

Davies' arguments are interesting for a number of reasons. First, the Reports is frequently cited for his statement that English law was "nothing else but the Common Custome of the Realm". ${ }^{11}$ Even within England this is problematic, reflecting legal legend more than practice. The common law had long since ceased to be a popular, rather than judicial, custom. ${ }^{12}$ Popular custom could, of course, become part of the law, for:

"When a reasonable act once done is found to be good and beneficiall to the people, and agreeable to their nature and disposition, then do they use it and practice it again and again, and so by often iteratiton and multiplication of the act it becometh a Custome; and being continued without interruption time out of mind, it obtaineth the force of a Law."13

But the determination of reasonableness remained with the court. ${ }^{14}$ In this way, common law mythology held that the law was "so formed and fitted to

8 Dedicated to Lord Ellesmere, Lord Chancellor of England, the work was originally written in the archaic law French that still dominated common law courts. $L a$ primer discours des cases et matters in ley (1615). I have cited from the anonymous translation, A report of cases and matters in law (Dublin, 1762). It is possible, as my law French remains imperfect, that this eighteenth-century translation, a decade after Montesquieu, may have modernised the text.

9 See notes on Charles O'Conor and Hume as well as O'Conor and the penal laws in Thomas Bartlett, The fall and rise of the Irish nation: the catholic question 16901830 (Dublin, 1992), 51-3.

10 Attributed to Davies, the "Lawes of Irelande" is a short, economical sketch of the later Discovery. Drawn from the Ellesmere collection of the Huntington Library, San Marino, California, it is reprinted by Hiriam Morgan as "'Lawes of Irelande': a tract by Sir John Davies", Irish Jurist (n s) 28-30 (1993-5) 307.

11 "[Continues] . . . consisting in use and practice . . . recorded and registered nowhere but in the memory of the people" - "Preface" to Reports, 3 .

12 On the "redaction" of custom into customary law, see Donald R. Kelley, "'Second nature': the idea of custom in European law, society, and culture", in Anthony Grafton and Ann Blair (eds), The transmission of culture in early modern Europe (Philadelphia, 1990) and James Q. Whitman, "Why did the revolutionary lawyers confuse custom and reason?", University of Chicago Law Review 58 (1991) 1321, 1331.

13 "Preface" to Reports, 3.

14 The distinction between "custom" and "law" remains a subject more appropriate to "law and anthropology" than to "historical jurisprudence". If, however, there is no easy metric by which to distinguish manners and laws, as norms are institutionalised and the province of legal experts, they become the antithesis of social practice. This is especially true where, as in Ireland, the experts and the people were so often of different traditions. See Stanley Diamond, "The rule of law versus the order of custom", Social Research 38 (1971) 42 and Peter Karsten, Between law and custom: "high" and "low" legal cultures in the lands of the 
the nature and disposition of this people, as we may properly say it is connatural to the Nation". ${ }^{15}$ Whatever the truth of English law being the common or 'connatural' custom of the realm within England, it was quite simply untrue, as Davies knew, for Ireland. That was the problem he set out to solve.

Invariably, Irish jurists and historians quoting from the Discovery select Davies' statement that there was:

"no nation of people under the sun that doth love equal and indifferent justice better than the Irish, or will rest better satisfied with the execution thereof, although it be against themselves, so as they may have the protection and benefit of the law when upon just cause they do desire it."16

Coming at the end of his work, in which he repeatedly criticised the backwardness of Irish culture, this is more rhetorical than real. No less than his contemporaries and predecessors, Davies believed English intervention required civilising the "wilde Irish" ${ }^{17}$ In most respects, his comments followed lost-established criticisms. The reliance of the Brehon laws, with many other pre-modern legal systems, on "ericks" or financial penalties for criminal offences shocked many English commentators. ${ }^{18}$ He criticised, too, customs like the "fostering" of children and "gossipred", the creation, by oath, of allegiances inimical to crown loyalties. ${ }^{19}$ In general, he noted, that:

"if we consider the nature of the Irish customs, we shall find that the people which doth use them must of necessity be rebels to all good government, destroy the commonwealth wherein they live, and bring barbarism and desolation upon the richest and most fruitful land of the world." 20

This barbarism extended to their law, in which:

"the weaker had never any remedy against the stronger . . . no man could enjoy his life, his wife, his lands or goods in safety if a mightier man than himself had an appetite to take the same from him. Wherein they were little better than cannibals, who

British diaspora-The United States, Canada, Australia, and New Zealand, 16001900 (Cambridge, 2002).

15 "Preface" to Reports, 6. "Long experience, and many trials of what was best for the common good, did make the Common Law". Id.

16 Discovery, 224.

17 See generally Joseph Th. Leerssen, Mere Irish \& Fior-ghael: studies in the idea of Irish nationality, its development and literary expression prior to the nineteenth century (Cork, 1996).

18 Given the frequency of capital punishment in the common law, this presumably owed more to a perceived failure to exact justice than to English sensibilities. In addition, as Harold J Berman has noted such fines were arguably more effective than capital punishment. Law and revolution: the formation of the Western legal tradition (Cambridge, MA, 1983), 55. See Discovery, 131 and 163.

19 See Discovery, 170-1. See Fiona Fitzsimons, "Fosterage and gossipred in late medieval Ireland: some new evidence" in Patrick J. Duffy, David Edwards, and Elizabeth FitzPatrick (eds), Gaelic Ireland c1250-c1650: land, lordship and settlement (Dublin, 2001).

20 Discovery, 163. 
do hunt one another, and he that hath most strength and swiftness doth eat and devour all his fellows." 21

Following Davies, I will "omit" discussion of "their common repudiation of their wives; their promiscuous generation of children; their neglect of lawful matrimony; their uncleanness in apparel, diet, and lodging; and their contempt and scorn of all things necessary for the civil life of man". ${ }^{22}$ If his writings were distinguished by an "optimism and proud consciousness", Davies' humanist gloss ought not obscure the deep hostility he felt towards Gaelic culture. ${ }^{23}$

Chief among the failures of Irish law was "tanistry" and what English jurists referred to as "gavelkind". ${ }^{24}$ Brehon traditions were, in fact, far less uniform than Davies suggests and he frequently misinterpreted Irish law in attempting to fit it into common law categories. In essence, tanistry was an elective system of kingship, whereby a "tanist" or heir-apparent was chosen by the tribe (túath) to succeed. This system, adapted to ensure 'worthy' kings, could result in violent competition as rivals sought to ensure their selection. ${ }^{25}$ In addition, a portion of the land in each tribe - and its lesser kin-groups (fine) - was attached to the office. ${ }^{26}$ In contrast, common contemporary practice of Europe's hereditary monarchies transferred kingship to the eldest male child or, if no male heir exists, to the eldest female. "Gavelkind", a legal term borrowed from an analogous legal practice in Kent, was more strictly related to real and personal property, involving paritable inheritance, the equal division between - as Davies saw it - all male children, within marriage and without. ${ }^{27}$ Again, this stood in sharp contrast with English primogeniture and the process of assigning shares could be complex. ${ }^{28}$

Both the hereditary monarchy and primogeniture were seen as serving as important stabilising forces by reducing the 'legitimate' challenges open to kingships and successions. In the Discovery, Davies wrote:

"In England and all well-ordered commonweals men have certain estates in their lands and possessions, and their inheritances descend from father to son, which doth give them encouragement to build and to plant and to improve their

21 Discovery, 163 (italics added). See Pawlisch 60-1. Spenser claimed that in the Munster famine, "they did eat the dead Carrions, happie wheare they Coulde finde them" cited in Andrew Hadfield, Edmund Spencer's Irish experience: wilde fruit and savage soil (Oxford, 1997), 66.

22 Discovery, 171. Note, too, the discussion of Irish craftiness and inquisitiveness at 168.

23 "Introduction" to Discovery, Myers (ed), 48.

${ }^{24}$ Cf Pawlisch, 61.

25 But "until election . . . the freehold of the land is in suspense" - "The case of tanistry" in Report, 94.

26 See Fergus Kelly, A guide to early Irish law (Dublin, 1988), 101. Defined at Discovery, n 18. See definition at $136 \mathrm{n}$ 198. This appears less communal than feudal.

27 Discovery, 164. In fact, kin-land (fintiu) was divided equally among all male children acknowledged by the group. Kelly, 102-3.

28 In one local variant, for example, the shares of the inheritance (orbae) were established by the youngest male (comarbae), who had then to wait as choice of the shares were made in order of age. See Kelly, 102. 
lands, and to make them better for their posterities. But by the Irish custom of tanistry, the chieftains of every country and the chief of every sept had no longer estate than for life in their chieferies, the inheritance whereof did rest in no man." 29

This is accurate to a degree. Unlike the common law, the central unit of the Brehon laws was the corporate kin-group. ${ }^{30}$ This suggested, for example, the joint responsibility of the group for the acts of its members, the principle of "Kincogish" (cin comhfhocuis). While this was frequently convenient for English authorities, as the individual's lack of authority to bind the group or kin-land also accounted for the putative failure of the natives to maintain existing agreements. ${ }^{31}$ In this way, tanistry "makes all their possessions uncertain and brings confusion, barbarism, and incivility". ${ }^{32}$ Instead, as Davies suggested, the Irish must be "permitted to purchase estates of freeholds or inheritance which might descend to their children according to the course of our common law". ${ }^{33}$ In the "Case of tanistry", in which Davies was (as attorney-general) counsel, the court eventually adopted his arguments about the role of the Brehon traditions in Ireland's "barbarism and desolation". ${ }^{34}$

Gavelkind applied more strictly to property than did tanistry, though the two are easily and understandably confused and property, especially that of land, continued to play an important political role as well. ${ }^{35}$ With gavelkind, as Davies saw it, the problem was not violence, but the instability involved in the fragmentation and reassessment of property holdings. In the Reports, "The resolution of the judges, touching the Irish custom of Gavelkind" notes that:

"By reason of these frequent partitions and removals or translations of the tenants from one portion to another, all the possessions were uncertain; and . . . was the very cause that no civil habituations were erected, no enclosure or improvement was made of the lands in the Irish countries where this custom ... was in use, especially in Ulster, which seemed to be all one wilderness, before the new plantation made by the English undertakers there ...." 36

29 Discovery, 164. See "The case of tanistry" in Reports, 92.

30 Individuals could, however, acquire a measure of control over land obtained through surpluses in farming or in a profession. Kelly, 101.

31 See "The case of tanistry" in Report, 92. Even lesser chiefs did not (typically) own their estates outright, but held only legal use (in a kind of usufruct or common law trust) for the period of the kingship.

32 Discovery, 136.

${ }^{33} I d$.

34 "The case of tanistry" in Reports, 92. The case is usefully summarised in F.W. Newark, "The case of tanistry", NILQ 9 (1950-2) 215.

35 See Kenneth Nicholls, Gaelic and Gaelicised Ireland in the middle ages (London, 1972), 63-4.

36 "The resolution of the judges, touching the Irish custom of Gavelkind" in Reports, 135-6. 
This "was the fruit of this Irish gavelkind". ${ }^{37}$ Together, tanistry and gavelkind:

"Made all their possessions uncertain, being shuffled and changed and removed so often from one to another by new elections and partitions; which uncertainty of estates hath been the true cause of such desolation and barbarism in this land, as the like was never seen in any country that professed the bane of Christ." 38

Indeed, Davies “boldly" claimed:

"that never any particular person, either before or since, did build any stone or brick house for his private habitation, but such as have lately obtained estates according to the course of the law of England. Neither did any of them in all this time plant any gardens or orchards, enclose or improve their lands, live together in settled villages or towns, nor made any provision for posterity; which being against all common sense and reason, must needs be imputed to those unreasonable customs which made their estates so uncertain and transitory in their possessions. For who would plant or improve or build upon that land which a stranger whom he knew not should possess after his death?" 39

Adopting such a worldview, it is not difficult to see merit in his criticisms. In general, neither Irish laws nor manners favoured economic improvement. ${ }^{40}$ But the possibility that "provision for posterity" might, in the more communitarian Gaelic culture, be in the maintenance of the kingroup, seems not to have occured to Davies. ${ }^{41}$

With this view, the "great defect" of English policy in Ireland was that "English laws were not communicated to the Irish, nor the benefit and protection thereof allowed unto them". ${ }^{42}$ Over several centuries, the people were "governed . . . by the Brehon law; they made their own magistrates and officers; they pardoned and punished within their several countries; they made war and peace one with another without controlment . ...43 As a

37 "The resolution of the judges, touching the Irish custom of Gavelkind" in Reports, 136. Cf Discovery, 143 on Welsh "gavelkind".

38 Discovery, 164.

39 Discovery, 165. "[T] law, would in those days pretend title still because by the Irish law no man could forfeit his land." - Discovery, 192.

40 Ireland lacked towns since "all held themselves to be gentlemen. . . [and] scorn to descend to husbandry or merchandise, or to learn any mechanical art or science." Discovery, 165-6. Cf Hiram Morgan, "The end of Gaelic Ulster: a thematic interpretation of events between 1534 and 1610", Irish Historical Studies 26 (1988) 8.

41 Nichols notes that when Davies "lays the blame for the under-development of rural Ireland on [Gavelkind, he was ... . ] confounding cause and effect; . . . such practices were the consequences of a low intensity of land use rather than its cause." - Land, law and society in sixteenth-century Ireland (Cork, 1978), 10.

42 Discovery, 135. "[T]hough", he wrote, "they earnestly desired and sought the same."-Discovery, 135.

43 Discovery, 76. 
result of being outside areas of effective Crown control, the "king's writ cannot run" and English law enforced. ${ }^{44}$ Given his role in the confiscation that would soon follow, it is interesting that Davies criticises past settlement patterns for excluding natives from good land, thereby promoting rebellion. ${ }^{45}$ More critically perhaps, the amount of discretionary authority awarded setters, especially through the creation of county palatines often obstructed London's attempts to maintain uniform political and legal control. ${ }^{46}$ Worse still, were the practical and theoretical problems associated with the Old English adoption of Irish manners and laws. ${ }^{47}$ This made "them slaves to that nation which they did intend to conquer". ${ }^{48}$ The failure of measures like the Statutes of Kilkenny (1366) to prevent the assimilation of settlers meant that "the Irish gave laws to them". ${ }^{49} \mathrm{He}$ repeatedly refers, too, as had earlier critics, to a variety of unjust and irregular Irish taxes or appropriations. ${ }^{50}$ But again, while it is not difficult to see some merit here, the continuing use, for example, of feudal fees against recalcitrant Irish, both native and Old English Catholics, in the years after Davies, makes this charge somewhat specious. ${ }^{51}$

This is not simply bad faith and Davies' actions show the necessity and efficacy of claims of legal justification in English policy. Among these elements was the use of conquest theory in the aftermath of the Nine Years' War. The "principal mark and effect of a perfect conquest" was, in the age of Bodin, "to give laws to a conquered people". ${ }^{2}$ When Davies noted that "to give laws unto a people; to institute magistrates and officers over them; to punish and pardon malefactors; to have the sole authority of making war and peace, and the like, are the true marks of sovereignty", he was doing little more than articulating an increasingly common assumption of European legal-political theory. ${ }^{53}$ The medieval problem was not the centralised state - or church - but its absence. The modern theory was contradicted not only by continuing Irish practices, but the overlapping authorities and

44 "The case of tanistry" in Reports, 102. In much of Ireland, England had neither formal nor practical sovereign authority. See Discovery, 199-200.

45 See Discovery, 160.

46 See Discovery, 147-61.

47 See Brady, "Spenser's Irish crisis: humanism and experience in the 1590s", Past \& Present 3 (1986) 17 and his "Reply", Past \& Present 120 (1988) 210, 213 (responding to Nicholas Canny's comments in "Debate", Past \& Present 120 (1988) 201).

48 Discovery, 154.

49 Discovery, 162. The statutes also left the natives "at large, to be ruled by their barbarous customs as they were before." - "The case of tanistry" in Report, 106. Discovery, 187-8. See Poynings at 197-8.

50 See Discovery, 83 (cess), 83-4 and 166-7 (coyne and livery), 94 (bonaught), 169 (cosherings, cessings, cuttings).

51 See H.F. Kearney, "The court of wards and liveries in Ireland, 1622-1641", Proceedings of the Royal Irish Academy 57 (1955-6) 29 and Victor Treadwell, "The Irish court of wards under James I", Irish Historical Studies 12 (1960) 1.

52 Discovery, 124. The French jurist Jean Bodin, whom Davies cites, would have been the best-known advocate of the modern theory of sovereignty in his Six books of the commonwealth (1576). A similar view had been solidifying throughout Britain and Europe, especially since the Reformation.

53 Discovery, 76. Such a "perfect conquest doth reduce all the people thereof to the condition of subjects ... governed by the ordinary laws and magistrates of the sovereign". - Discovery, 71. 
decentralisation of pre-Reformation Europe. Indeed, while an effective state apparatus was an ever more important part of English governance, the Brehon laws were decidedly pre-modern. Ireland had never had a national state or legal system. The Brehons themselves were more accurately arbiters to whose decision the parties agreed to abide rather than magistrates. The force of their 'judgments' was more moral than political, owing as much to manners as to law or sanctions enforced by political institutions. This decentralisation of judicial authority may have initially slowed the encroachment of a common law, but it also made the native tradition more difficult to defend.

In a number of extraordinary actions, Davies sought to make this concept of sovereignty practically effective in Ireland through a process of judicial conquest. $^{54}$ The English government's general pardon following the Nine Years War had largely restored rebels to their estates. Effectively reinterpreting the settlement of 1603, Davies used a controversial theory of "alieanage" whereby the Irish were treated under English law as aliens, rather than subjects, without formally submitting to English law. ${ }^{55}$ Existing legal relationships were remoulded into analogous, though often inappropriate, English law formulas. Ulster's under-chiefs could thus be seen as having "freeholds", against the claims, and claimed infringement, of Hugh O'Neill. Court-stacking by "New", rather than "Old", English magistrates, and the issuance of extra-judicial resolutions, by a majority of these judges acting in conclave outside of live legal controversies in the central courts, voiding Gaelic tenures (1606) further strengthened the options available to other courts. ${ }^{56}$ The courts could also determine that Brehon 'customs', being inherently unreasonable, failed to meet judicial requirements for incorporation into the common law. This again resulted, in part, by the determination that a 'good' custom could not be contrary to a conception of the common good defined according to English standards. ${ }^{57}$ In addition, by applying the modern theory of sovereignty, and assuming tanistry and gavelkind to be common and uniform throughout Ireland, they effectively claimed to have replaced Brehon law in its entirety, for "it must of necessity be abolished by the establishment of another general law in the same point". 58

With the flight of the earls, arising partly through the political and the legal pressure of men like Davies, whose personal animosity towards O'Neill was

54 Hans S Pawlisch, Sir John Davies and the conquest of Ireland (Cambridge, 1985), 14.

55 The Irish could not make claims without making formal submission by "charters of denization".

56 These were followed, most notably in the "Case of tanistry", in a manner surprisingly akin to modern theories of precedent. See Discovery, 218. On precedent, see Berman, "The origins of historical jurisprudence: Coke, Selden, Hale", Yale Law Journal 103 (1994) 1651.

57 Davies quoted a statute of Kilkenny (c 4, enacted in 40 King Edward III) stating that "the brehon law. . ought not to be named a law, but an evil custom". Discovery, 139.

58 "The case of tanistry" in Report, 101. See Pawlisch, 45. 
well-known, the opportunity arose for seizing at once vast tracts of Ulster. ${ }^{59}$ To do this, Davies changed tactics and, reinterpreting the Ulster lands again into Brehon terms, or his interpretation of them, he argued that no freeholders existed. This essentially credited O'Neill's claims, but in the Earl's absence, Davies maintained that the lands passed instead to King James in a residual claim (under conquest theory) as lord paramount. This ignored the fact that the kin-centred Brehon law, just as in English corporation theory the death of a natural person did not terminate the legal life of the "corporation", would have reallocated "shares" to the remaining members of the corporate group. More surprisingly, Davies portrayed the remaining Irish as beneficiaries of the King's 'civilising' of Ireland, though this involved both confiscation of the lands they occupied and their transportation from those lands. Davies claimed, indeed, that the native Irish embraced English law. In conditions little short of martial law, it is unsurprising that they would flock to the common law courts and commissions in order to find any security they might. ${ }^{60}$ They would be largely disappointed.

As a result of these actions, Davies could quickly point to a number of successes. ${ }^{61}$ The judiciary could claim that "the common law hath been communicated to all persons, and executed through all this kingdom" and the country was finally "well settled". ${ }^{62}$ There was, he wrote, "one king, one allegiance, and one law". ${ }^{63}$ As a result, there was "such comfort and security in the hearts of all men as thereupon ensued the calmest and most universal peace that ever was seen in Ireland." 64 The Irish were "encourage[d] to build, to plant, to give better education to their children, and to improve the commodities of their lands". ${ }^{65}$ Crime, he claimed, was immediately lessened. ${ }^{66}$ The English laws also had an immediate effect on manners, for:

"These civil assemblies at assizes and sessions have reclaimed the Irish from their wildness; caused them to cut off their glibs [bangs] and long hair, to convert their mantles into cloaks, to conform themselves to the manner of England in all their behavior and outward forms." 67

Here the mere necessity of having to submit to English courts meant:

59 See Harris, "The commission of 1609: legal aspects", Studia Hibernica 20 (1980) 31 and GA Hayes-McCoy, "Sir John Davies in Cavan in 1606 and 1610", Breifne 1 (1960) 188-91.

60 See Harris, "The state of the realm: English military, political and diplomatic responses to the Flight of the Earls, autumn 1607 to spring 1608", Irish Sword 14 (1980) 47, 61.

61 "The case of tanistry" in A report of cases and matters in law, 86. See Coke at Pawlisch, 63.

62 "The case of tanistry" in Reports, 108, 115. Cf Discovery, 135.

63 Discovery, 138.

64 Discovery, 213.

65 Discovery, 221. "Briefly, the clock of the civil government is now well set, and all the wheels thereof do move in order". Discovery, 223. See 223.

66 See 216 on the reduction of crime and note that "the truth is that in time of peace the Irish are more fearful to offend the law than the English or any other nation whatsoever"- Discovery, 216.

67 Discovery, 217. 
"because they find a great inconvenience in moving their suits by an interpreter, they do for the most part send their children to schools, especially to learn the English language: so as, we may conceive an hope that the next generation will in tongue and heart, and every way else, become English, so as there will be no difference or distinction but the Irish Sea betwixt us." 68

In sum, "execution of the law doth make the Irish grow civil and become English". ${ }^{69}$

Given the overlap in Irish tradition of lawyers and poets, it is unfortunate the jurist-poet had so little sympathy with native culture. The judicial colonisation and conquest he oversaw, kinder and gentler perhaps than that envisioned by men like Edmund Spenser, no less effectively undermined Gaelic society. ${ }^{70}$ This is not to suggest, as Davies sometimes does, that lawgivers could introduce manners at will, but his actions and writings set important legal and historiographical precedents. ${ }^{71}$ In practical terms, they "established a paradigm for British expansion elsewhere". ${ }^{72}$ The focus on law rather than confessional differences also suggested a seemingly neutral scheme of social development, conducive to its acceptance by later 'enlightened' authors. Perhaps most important to eighteenth-century British and Irish historiography was David Hume, who believed Davies to be Ireland's only "philosophical historian" and adopted many of his arguments. $^{73}$

$68 I d$. "And thus we see a good conversion, and the Irish game turned again." - Id The Irish game was a variation of backgammon was characterised by rapid changes in fortune. See "Introduction" to Discovery, 54-5. This metaphor, Myers writes, "conceals several morally objectionable realities and misrepresents certain equally dubious cultural developments". "Introduction" to Discovery, 56. See also Discovery, 59.

69 Discovery, 217.

70 It may be of interest to note that Davies was a poet of the Spenserian school. Best known as the author of the Faerie Queen (1590-6), Spenser had served as an administrator in Ireland. While drawing on common Elizabethan-Jacobean perceptions of Ireland, his approach was especially severe in its recommendation of military terror and famine. See Spenser, A view of the present state of Ireland (Oxford, 1970 [1598]), WL Renwick (ed). Perhaps because of its harsh prescriptions, the work remained unpublished in his lifetime. It was, however, entered into the register of the Company of Stationers in 1598 and was available in circulation. Burke would have familiar with the edited and muted version published in Sir James Ware (ed), Ancient Irish histories (1633), the unabridged text not being in print until the nineteenth century.

71 Cf Davies' preface to Reports, 15-6, esp. his comments on commercial improvement and "luxurie". "[I]f we all lived according to the Law of Nature, we should need few laws, and fewer lawyers. . . . And again, if we were a poor and a naked people, as many Nations in America be, we should easily agree to be judged by the next man we meet..." - Reports, 16 .

72 Pawlisch, 14. On Davies' work as "political propaganda", see Myers' "Introduction" to Discovery, Myers (ed), 53.

73 Hume's History of England (1754-62) followed Davies closely, viewing the native Irish as savages civilised by English conquest (and some Scottish arms). See esp. History of England (1762), vi.58-61. 


\section{A Rude And Barbarous People}

All of this will seem very remote from Edmund Burke, born a century after Davies' death, a period in which many see a shift in Ireland from colony to ancien régime. ${ }^{74}$ In that time, Ireland saw the rebellion of 1641, Cromwell, Restoration and the Irish Act of Settlement, the Williamite wars, and the enactment of the penal statutes. Burke's family was no less affected than were others in Ireland..$^{75}$ His father, a Dublin attorney, appears to have been a converso, perhaps simply to avoid restrictions on the legal profession. As Burke's mother remained a catholic, Richard Burke only narrowly avoided a later statute (1733) barring those marrying catholics thereafter from practice. ${ }^{76}$ Not only did "Ned" have numerous catholic relations, not least his sister, but his earliest education appears to have been in a hedge-school in the Blackwater valley of county Cork, perhaps even in Irish. ${ }^{77}$ After Trinity College (Dublin) and legal studies in England, Burke began a literary career with A philosophical enquiry into the origins of our ideas of the sublime and the beautiful (1757), collaboration on the ethnographic Account of the European settlements in America (1757), and the post of editor for the Annual Register. These were insufficient income, however, for his young family and Burke found his first political employment not in England, but in Ireland. He was personal secretary to the Irish chief secretary, William Hamilton, when the "Whiteboy" disturbances of Munster erupted in the 1760s. While these occurred as the result of general agricultural changes from tillage to pasturage, the response of the Dublin government was harsh and sectarian, and members of Burke's extended family were implicated. The episode indicated that the defence of the catholic majority was often best accomplished in appeals to London, rather than to Dublin. Burke's parliamentary career, and his virtual silence at the time of Irish legislative independence (1782), grew in part from such experiences. ${ }^{78}$

74 See, e.g., SJ Connolly, "Eighteenth-century Ireland: colony or ancien regime?" in D George Bryce and Alan O'Day (eds), The making of modern Irish history: revisionism and the revisionist controversy (London, 1996).

75 There are recurrent efforts to remind the public of the "Irish" Burke. Conor Cruise O'Brien's The great melody: a thematic biography and comment anthology of Edmund Burke (London, 1992) is a good recent example, but he somewhat overstates the case. $C f$ Michael Fuchs, Edmund Burke, Ireland, and the fashioning of self (Oxford, 1996).

767 Geo. II, c 5 (Stat. Ire.). See Colm Kenny, "The exclusion of catholics from the legal profession in Ireland, 1537-1829”, Irish Historical Studies 25 (1987) 337, esp. 354.

77 See LM Cullen, "The Blackwater Catholics and County Cork society and politics in the eighteenth century", in Patrick O'Flanagan and Cornelius G Burrimer (eds), Cork History and society: interdisciplinary essays in the history of an Irish county (Dublin, 1993). Burke's library included an Irish-English dictionary, an Irish catechism, and a copy of Thomas á Kempis in Irish. Evidence that he spoke Irish later in life is not entirely convincing. An early Scottish biographer claimed that Burke spoke, by way of Irish, with an elderly Scot about the Ossian stories. Robert Bisset, Life of Edmund Burke ( $\left(2^{\text {nd }}\right.$ edn) London, 1800), ii.447-8. There is also a note by the less than trustworthy Charles Vallancey. See Walter D Love, "Edmund Burke, Charles Vallancey and the Sebright manuscripts", Hermathena 95 (1961) 21, 34.

78 See "A candid enquiry into the causes and motives of the late riots in the province of Munster, together with a brief narrative of the proceedings against the rioters, 
In Ireland in the $1760 \mathrm{~s}$, Burke befriended several members of the Irish Catholic Committee, including Charles O'Conor of Belanagare and Dr John Curry. He began, too, his best-known 'Irish' work, the Tracts on the popery laws (c 1759-65). ${ }^{79}$ Never published, several versions of the Tracts circulated in the following decades among members of the English and Irish administrations. They continue to be seen as a foundational text in Irish historiography of the eighteenth-century, not least in the interpretation of the penal laws. ${ }^{80}$ While modern scholarship has tended to emphasise that the statutes passed effectively into desuetude, they were never entirely a dead letter. ${ }^{81}$ In 1778, for example, Curry wrote to Burke noting:

"It will . . . be no small addition to your dislike of our Popery laws, that your old \& worthy acquaintance Charles O'Connor, now at the Eve of life, is actually smarting under the lash of them, from the hand of [Hugh,] his younger brother, lately reconciled to the established religion, for the pious purpose of robbing him of the poor remains of his very ancient, \& once ample, inheritance." 82

In general, the Tracts underscored the continuing indignity of the laws, the perversion of the sentiments of the "little platoons" of family and community, of protestant discoverers or informers, and the corrupting effect of such laws on both islands. ${ }^{83}$

The perversion, too, of the legal and social orders was no small concern. When he later refused $£ 300$ from the Catholic Committee, Burke claimed his "uniform principle" was:

"an utter abhorrence of all kinds of public injustice and oppression, the worst species of which are those which being converted into maxims of state, and blending themselves with law and jurisprudence corrupt the very fountains of all equity, and subvert all the purposes of Government." 84

anno 1766" in the Burke Papers of the Wentworth Woodhouse Muniments (hereinafter "WWM Bk P") at the Sheffield Archives, 8/1. It is also included in the Correspondence of the Right Honourable Edmund Burke (London, 1844), i. 41-5.

79 Included in The writings and speeches of Edmund Burke (Oxford, 1997 (10 vols)), Paul Langford (general ed), i.434-82 (hereinafter "WS"). See also WWM Bk P $27 / 205$, listing the penal laws in outline (and quoting Blackstone's criticism).

80 See Cullen, "Catholics under the penal laws", Eighteenth-Century Ireland/Iris an dá chultúr 1 (1986) 23 and Eamon O'Flaherty, "Burke and the catholic question", Eighteenth-Century Ireland/Iris an dá chultúr 12 (1997) 7.

81 See SJ Connolly, Religion, law and power: the making of protestant Ireland (1992), CDA Leighton, Catholicism in a protestant kingdom: a study of the Irish ancien régime (1996), and Niall Osborough, "Catholics, land and the Popery Acts of Anne" in Studies in Irish legal history (Dublin, 1999).

82 Curry to Burke (7 June 1778) in WWM Bk P 1/1062. For a time, O'Conor was under house arrest.

83 See WS i. 481-2.

84 Burke to Curry (14 August 1779) in The correspondence of Edmund Burke (Cambridge, 1981 (10 vols)), Thomas W. Copeland (general ed), iv.118 (hereinafter " $\mathrm{C}$ "). 
It is essential in reading the Burke's later reflections on European revolution and the British constitution, to remember that he was aware of its significant limitations in Ireland. ${ }^{85}$ While he brought to his analysis in the Tracts remarkable intellectual, legal, and rhetorical abilities, his arguments were not entirely novel, but closely reflected the thought of the Catholic Committee. ${ }^{86}$ Like them, Burke - in appeals to reason, natural law, and history-paid particular attention to the fragmentation and insecurity of catholic propertyholding and sought to show how the laws in action undermined the national interest of Ireland. The laws, Burke wrote, "entirely change the course of Descent by the common Law. They abrogate the right of primogeniture; and . . . substitute a new Species of Statute Gavelkind". ${ }^{87}$ This penal gavelkind, as in the case of O'Conor, played on family division by encouraging, though far from successfully, conversion and confiscation. ${ }^{88}$ Burke saw their purpose as:

"that, probably in the first generation, but certainly after a few descents, the Landed property of Roman Catholicks should be wholly dissipated; and. . . their families. . . reduced to obscurity and indigence, without a possibility that they should be restored by any exertion of industry or ability, being disabled. . . from every species of permanent acquisition. .."89

Restrictions existed, too, on:

"the acquisition of landed property, which is the foundation and support of all the other kinds, [but] the Laws have disabled three-fourths of the inhabitants of Ireland from acquiring any estate of inheritance for life or years, or any chance whatsoever on which two-thirds of the improved yearly value is not reserved for 30 years.

85 See the notes on the "State of Ireland" in the 1770s at WWM Bk P 8/192-3.

86 Thomas McLoughlin notes, "In Burke's 'Plan', Chapter Four, headed, 'The Impolicy of those Laws as they Affect the National Security,' looks like the climax, even though we do not have the final chapter . . . entitled 'Reasons by which the Laws are supported and Answers to them'." - "Burke's dualistic vision in the Tracts on the popery laws", Études Anglaises 34 (1981) 180, 187.

87 WS ix. 436 (to "proceed ad infinitum"). See WS ix. 444. Gavelkind was, in the sixteenth century, "probably" the established method of inheritance among "the Burkes of Counties Tipperary and Limerick", from which Burke was descended. K.W. Nicholls, "Some documents on Irish law and custom in the sixteenth century", Analecta Hibernica 26 (1970) 105.

88 The promise of gain through conformity was a threat that children held over their parents, wives above their husbands, and siblings against one another. In this way, "Hope and fear, love and gratitude, despondence and protection, should be entirely extinguished in all such families, so that with regard to the important points of donation, testament, settlement, and Descent, the whole Order of the common Law is changed and subverted ... [and this] is still a more sensible departure from the Spirit of the common Law ... (WS ix. 437)". See WS ix.438.

89 WS ix. 437. See WS i. 442 and $c f$ WS ix. 444. See also "Hints on circulation" contrasting, without reference to confessional differences, the aggregation of wealth in the gentry from 1685-1762. F(M) xxiv. 24 of the Fitzwilliam (Milton) Burke Collection at the Northampton Record Office. See WS ix. 615 and discussion below. 
This confinement of landed property to one set of hands, and preventing its free circulation through the community, is a most leading article of ill policy; because it is one of the most capital discouragements to all that industry which may be employed on the lasting improvement of the soil, or is any way conversant about land. A tenure of 30 years is evidently no tenure upon which to build; to plant; to raise enclosures; to change the nature of the ground; to make any new experiment which might improve agriculture; or to do anything more than what may answer the immediate and momentary calls of rent to the landlord and leave subsistence to the tenant and his family." 90

It is at least ironic that a form of Gavelkind criticised as undermining social improvement, should become the means of maintaining, or fostering, decline. It was, he wrote, "as if the Law had said in express terms, "Thou shall not improve". 91

These views on property and progress, insofar as it is possible to compare such vastly different contexts as the early seventeenth and mid-to-late eighteenth centuries, were broadly similar to those of Davies. In the period in which he wrote the Tracts, Burke also began, though never entirely completed, an Abridgement of the English history (c 1757-62). ${ }^{92}$ In discussing Irish history there, he was not uncritical. "[T]he people of Ireland", he wrote, "lay claim to a very extravagant antiquity, through a vanity common to all nations". ${ }^{93}$ More surprising may be his belief that the Irish had often clung too closely to the past. Among outdated Irish customs was tanisty, which "prevailed in Ireland some hundreds of years after the rest of Europe", ${ }^{94}$ These were, Burke agreed, "attended with very great and pernicious inconveniences". 95 Such observations were, however, part of a wider analysis. Without contradicting Davies, Burke believed tanistry to have been nearly universal in European systems of property and successions. $\mathrm{He}$ made use of it to critique both whig and tory accounts of English constitutional history. ${ }^{96}$ As tanistry was "made up of inheritance and election", he wrote in the Abridgement, the "controversy, which has been managed with such heat, whether in the Saxon times the crown was hereditary or elective, must be determined, in some degree, favourably for the litigants on either side; for it was certainly both . . . within the bounds, which we have mentioned". ${ }^{97}$ This developed slowly over time, so that the

90 WS ix. 476-7.

91 WS ix. 477. See WS ix. 445.

92 See the Abridgement towards an abridgement of the English history at WS i.332552. See also the "Fragment: An essay towards a history of the laws of England (c 1757)" in WS i.321-31.

93 WS i. 509. See WS i.511.

94 WS i. 433. "[U]ntil the beginning of the last century (WS i. 433)".

95 WS i. 511. "[I]t was obviously an affair of difficulty to determine who should be called the worthiest of the blood; and a door being always left open for ambition, this order introduced a greater mischief than it was intended to remedy (WS i. 511)".

96 WS.i. 433.

${ }^{97} \mathrm{Id}, \mathrm{Id}$. 
"leader neither knew the extent of the power he received, nor the people of that, which they bestowed". ${ }^{8}$ Burke's analysis throughout the work admittedly extending only to the Magna Charta - is remarkably free of Hume's hostility towards either the clergy or the Irish. It remains, with the related "Fragment" on law, an invaluable document, though often overlooked source for understanding Burke's views on law, manners, and history. ${ }^{99}$

The relationship between law and manners in history had long been important to European legal humanists. ${ }^{100}$ Before the more advanced analyses of Vico and Montesquieu, even Davies had noted such connections among both the Amerindians and English. ${ }^{101}$ Burke, in his collaboration with Middle Temple fellow William Burke on the Account of the European settlements in America, observed that the "infant settlements" even of the colonists "surely demanded a more simple, clear, and determinate legisllation" as laws must be "suited to the time, to their country, and the nature of their . . . way of life". ${ }^{102}$ Of more interest, in discussing the Amerindians, the Burkes wrote how they were "[g]overned . . . by manners, not by laws". ${ }^{103}$ Indeed, in such societies, these "customs operate amongst them better than laws ... they become sort of nature to the governours and the governed". ${ }^{104}$ This distinction between laws and manners, between social mores and formal institutions recurs throughout Burke. With the dichotomy, at least formally, between nature and art, it is at the centre of his thought on both culture and jurisprudence. Indeed:

"Manners are of more importance than laws. Upon them, in a great measure, the laws depend. The law touches us but here and there, and now and then. Manners are what vex or soothe, corrupt or purify, exalt or debase, barbarize or refine us, by a constant, steady, uniform, insensible operation, like that of the air we breathe in. They give their whole form and colour to

98 WS i. 434. The Saxon government "was never supported by any fixed or uniform principle", he wrote, and it was "no wonder, that the advocates for the several parties among us find something to favour their several notions (WS i. 435)".

99 See Donlan, "Beneficence acting by a rule: Edmund Burke on law, history, and manners", Irish Jurist (n s) 36 (2001) 227.

100 As the history of historiography attests, legal humanists were among the forefathers of modern history and hermeneutics. See esp. Donald R Kelley, Foundations of modern historical scholarship: language, law, and history in the French Renaissance (New York, 1970) and The human measure: social thought in the Western legal tradition (Cambridge (MA), 1990).

101 See the preface to Reports, 16 (on the "poor" and "naked" of America) and 15 (on contemporary European wealth and contract).

102 An account of the European settlements in America (hereinafter "AES"), ii.304. Citations to volume one are made from the 1766 printing (London, 1766), those to volume two to that of 1758 ( $\left(2^{\text {nd }} e d\right)$ London, 1758).

103 AES i. 168.

104 WS i. 430. See AES i.167-9 and cf An essay towards an abridgement of the English history, WS i. 430 (on the Germans), 447 (on the Saxon polity). 
our lives. According to their quality, they aid morals, they supply them, or they totally destroy them."105

Given the fact that, in Ireland, Irish catholics - and indeed dissenters - often fell outside of the protection of the law, such a focus is not surprising. Burke would not always have agreed with O'Conor's defence of Irish institutions, which in many ways transposed English models to the Irish past. But he would have found little fault in the wider point that Irish institutions like tanistry, ericks, etc., could be entirely appropriate for the times. ${ }^{106}$

O'Conor sometimes portrayed the ancient Irish as commercial, and even united. Burke would have been suspicious of such a projection, which seems again to make the Irish more anglicised than the English themselves. But his experiences in Ireland and his knowledge of its history may have influenced his unique understanding of the relationship between culture and commerce. Whatever the truth about ancient Ireland, Burke was far more suspicious than were his Scottish associates - Adam Smith, William Robertson, and John Millar - of discrete stages of progress from rudeness to refinement. He was just as sceptical about the prioritisation of commerce over manners that many of the Scottish enlightenment appeared to suggest. He consequently remained far more supportive of the virtues of primogeniture, landed property, and the "moral economy". ${ }^{107}$ From the Tracts on, Burke underscored the "happy alliance" of commercial and agricultural interests and very real, if legally "imperfect" obligations. ${ }^{108}$ Indeed, even the penal laws left surprisingly little restriction on trade and movable wealth. In one of his last comments on the laws, Burke noted that:

"The system of laws which, by a perversion of all legal principles, and by various contrivances of vexation, had screwed the Roman Catholics out of their landed property, and in the same process broken the spirit of their gentry, [they had] forced a commercial interest to grow up in its place." 109

That a "monied interest" was not an unalloyed good, was a point of some importance in Burke's Reflections on the Revolution in France and on the proceedings in certain societies in London relative to that event (1790). ${ }^{110}$ In

105 Letter one (1796) of Letters on a regicide peace (Indianapolis, 1999 [1975-7]), 126. For if "laws are corrupted. Whilst manners remain entire, they will correct the vices of law, and soften it at length to their own temper (WS iii. 299)".

106 See O'Conor, "Of the laws of tanistry and eric, \& c" in Dissertations on the history of Ireland (( $3^{\text {rd }}$ ed $)$ Dublin, 1812).

107 See EP Thompson, "The moral economy of the English crowd in the eighteenth century", Past \& Present 50 (1971) 76.

108 WS ix. 478.

109 "On the state of Ireland" (c 1792) in Correspondence of the Right Honourable Edmund Burke, iv. 85. See Cullen, "Catholics under the penal laws", esp 29, Maureen Wall, "The rise of a catholic middle class in eighteenth-century Ireland" in George O'Brien (ed), Catholic Ireland in the eighteenth century: collected essays of Maureen Wall (Dublin, 1989), and Kevin Whelan, "An underground gentry?: catholic middlemen in eighteenth-century Ireland", Eighteenth-Century Ireland/Iris an dá chultúr 10 (1995) 7. See WS i. 478.

110 See JGA Pocock, "The political economy of Burke's analysis of the French Revolution" in Virtue, commerce, and history: essays in political thought and history, chiefly in the eighteenth century (Cambridge, 1985) and "Edmund Burke 
his general defence of the modern civil - or civilised - society, manners were not merely "of more importance than laws", but than commerce as well.

If there is a real sense, practically and philosophically, in which Burke lived in an anglicised world that Davies helped to create, he presents a very different account of the English settlements in Ireland. ${ }^{111}$ He approached the eclipse of the Brehon laws, for example, and the slow decline of the Irish language regretting:

"the narrow notions of our lawyers, who abolished the authority of the Brehon law, and at the same time kept no monuments of it; which if they had done, there is no doubt but many things of great value towards determining many questions relative to the laws, antiquities and manners of this and other countries had been preserved." 12

Burke himself collected numerous "monuments" of the Irish past and helped others - Thomas Leland, Dr Sylvester O'Halloran, Charles Vallancey, and Thomas Campbell - to ensure that such materials were preserved. ${ }^{113}$ Most notably, O'Conor followed Burke's suggestion that ancient Irish materials, including legal tracts, be translated before they were completely lost to future generations. Unfortunately, the man best able to achieve this, Francis Stoughton Sullivan (1719-66), Trinity College's first professor of feudal and common law, died before completing much of the translation of the Annals of the four masters. ${ }^{114}$

Burke's complex response, too, to the primitivism of 'Ossian', the partly found, partly constructed poetry of Scottish writer James Macpherson, is

and the Redefinition of Enthusiasm: the context as counter-revolution" in François Furet and Mona Ozouf, (eds), The French revolution and the creation of modern political culture: vol 3, the transformation of political culture 1789-1848 (Oxford, 1990).

111 Burke seems to have contemplated writing an Irish history. On Burke and Irish history, see John C Weston, Jr, "Edmund Burke's Irish history: a hypothesis", PMLA 77 (1962) 397 and Love, "Edmund Burke, Charles Vallancey and the Sebright manuscripts"; Idem, "Charles O'Conor of Belanagare and Thomas Leland's 'philosophical' history of Ireland", Irish Historical Studies 13 (1962) 1; and Idem, "Edmund Burke and an Irish historiographical controversy", History and Theory 2 (1962-3) 180.

112 WS i. 433. In his review of Ferdinando Warner's The history of Ireland (1763), Burke noted that "we could wish . . . the doctor had been a little fuller in his account of Tanistry and the Brehon law". Annual Register (1763) 258 (second pagination).

113 O'Halloran, whose History of Ireland (1772) Burke owned, wrote him with information on the Burkes of Limerick and sent him several Irish artefacts. See J.B. Lyons, "The letters of Sylvester O'Halloran (second part)", North Munster Antiquarian Journal 9 (1962-3) 25. See also the numerous Irish titles in Burke's published library catalogues. See Seamus Deane (ed), Sale catalogues of libraries of eminent persons: Volume 8 - Politicians (London, 1973) and the Catalogue of the library of the late Right Hon Edmund Burke in Oxford's Bodleian Library (Ms Eng Misc d 722).

114 There remains no satisfactory account of the life of Sullivan or analysis of his Lectures on the constitution and laws of England (1770; $2^{\text {nd }}$ edn 1776). See Leslie Stephens and Sidney Lee (eds), The dictionary of national biography (London, 1885-1901), xx. 162. 
instructive. Its arguably Irish sources and the concomitant attempt by Burke's intellectual allies to stress the civility of Irish manners before English conquest and commerce created numerous dilemmas. ${ }^{115}$ While he expressed doubt immediately, Burke wrote that the works gave "a striking picture of the manners, the customs, the superstitions of the times . . . [and] seem utterly beyond the reach of any modern invention". ${ }^{116} \mathrm{He}$ went so far as to claim that the writing was "really Irish in an English dress" and, even in translation, it preserved "the majestic air, and native simplicity of a sublime original". ${ }^{117}$ Interestingly, Hume wrote to the Reverend Hugh Blair, who introduced the work, of Burke's comment:

"that on the first publication of Macpherson's book, all the Irish cried out, we know all these poems, we have heard them from our infancy. But when he asked more particular questions, he could never learn, that any one had ever heard, or could repeat the original of any one paragraph of the pretended translation." 118

Under the criticism of his friends, Dr. Samuel Johnson and O'Conor, it became increasingly clear to Burke that the work was at least partially forged. But they remained, even with Hume and other Scots, attractive fictions.

It is Burke's comments on Irish history which best illustrate differences not only with Davies, but with many of his protestant Irish friends and English colleagues. In a letter of 1792, Burke stressed that the native Irish were held in contempt by the "civilising" English long before the eighteenth-century. The "statutes of Kilkenny" indicated "that the spirit of the popery laws, and some of their actual provisions, as applied between Englishry and Irishry, had existed in that harassed country before the words Protestant and Papist were heard of in the world". ${ }^{119}$ Burke singled out Davies, with Spenser and Finglass, as examples of the "true genius and policy of the English

115 On the different Irish and Scottish responses, see Clare O'Halloran, "Irish recreations of the Gaelic past: the challenge of Macpherson's Ossian", Past and Present 124 (1989) 69; Idem, "Golden ages and barbarous nations: antiquarian debate on the Celtic past in Ireland and Scotland in the eighteenth century" (unpublished PhD, University of Cambridge 1991); Colin Kidd, "Gaelic antiquity and national identity in enlightenment Ireland and Scotland", 1994 English Historical Review 1197, 1198. See also Kidd, British identities before nationalism: ethnicity and nationhood in the Atlantic World, 1600-1800 (Cambridge, 1999).

116 Annual Register (1761) 278 (second pagination). See Annual Register (1760) 253-4 (second pagination) and (1761) 282 (second pagination)).

117 Annual Register (1761) 279, 276 (second pagination). Macpherson may, in fact, have drawn from Burke's Enquiry. See LL Stewart, "Ossian, Burke and the 'Joy of Grief", English Language Notes 15 (1977) 1.

118 (19 Sept 1763) in JYT Grieg (ed), The letters of David Hume (1969), i.400.

119 WS ix. 615. See generally Burke's Letter to Sir Hercules Langriche (1792) (WS ix. 594-639) and "Letter to Richard Burke (post 19 February 1792)" (WS ix. 64058). See also RE Burns, "The Irish penal code and some of its historians", Review of Politics 21 (1959) 276. 
government". ${ }^{120}$ Davies, he says, "boasts the benefits received by the natives, by extending to them the English law... [while] the appearance of things alone changed". ${ }^{121}$ The promised improvement never came, but instead there were "unheard of confiscations" and "under pretence of tenures, and then of titles in the crown, for the purpose of the total extirpation of the interests of the natives in their own soil". ${ }^{122}$ These actions:

"kindled at length the flames of that rebellion which broke out in 1641. By the issue of that war, by the turn by which the Earl of Clarendon gave to things at the restoration, and by the total reduction of the kingdom of Ireland in 1691; the ruin of the native Irish, and in a great measure too, of the first races of the English, was completely accomplished." 123

Again, all of these events precede the penal statutes. For all the rhetoric of the Tracts, Burke knew that the penal laws were not the cause of English and Irish protestant hegemony, but an attempt at securing the protestant - more accurately Anglican - interest.

As a good whig, Burke believed, the Glorious Revolution to have been a watershed for English liberty and public virtue, and he hoped Ireland would, in future, benefit from its connection with England. But the revolution "operated differently" in the two. ${ }^{124}$ "In Ireland," he wrote:

"it was the establishment of the power of the smaller number, at the expense of the political liberties and properties of the far greater part; and at the expense of the political liberties of the whole. It was, to say the truth, not a revolution, but a conquest." 125

This distinguished the Irish situation from similar restrictions across the continent on protestant and catholic alike. ${ }^{126}$ Ireland's long seventeenth century began with the elimination of the Brehon tradition in hopes of improving the mores and material goods of the native Irish through equal treatment under law. Whatever the reality of this ideal, the century ended with the legislative attempt, admittedly piecemeal and often ineffective, at eroding or containing Irish catholicism and commerce. Burke implies what O'Conor made explicit in unfavourably contrasting Hume's "declamation against the Tanistry Laws . . . with the Popery Laws since King William's

120 WS ix. 615. Finglass' Breviat of the getting of Ireland and of the decaie of the same, written in the sixteenth century, was published in Hibernica: or some ancient pieces relating to Ireland (1747).

121 WS ix. 615.

$122 I d$, WS ix. 616.

123 Id.

124 WS ix. 614.

125 Id (italics added). "All the penal laws of that unparalleled code of oppression, which were made after the last event, were manifestly the effects of a national hatred and scorn towards a conquered people ... (WS ix. 616)".

126 Burke did not claim, as the nineteenth-century Irish historian WEH Lecky suggested, that the penal laws were inspired by the laws of Louis XIV against the Hugenots. See WS ix. 459-60. 
demise". ${ }^{127}$ In his own arguments with Hume, Burke "considered himself . . . as referred to on the subject". ${ }^{128}$ Against what he believed to be the insulting and dehumanising contemporary histories of Ireland, Burke hoped for:

"an interior history of Ireland, the genuine voice of its records and monuments, which speaks a very different language. . . : these restore Nature to its just rights, and policy to its proper order. For they even now show to those who have been at the pains to examine them, and they may show one day to all the world, that these rebellions were not produced by toleration, but by persecution - that they arose not from just and mild government, but from unparalleled oppression." 129

Without claiming, then, that the Irish saved civilisation, Burke granted its native and catholic cultures a status denied them by many British and Irish protestant historians.

A final comment is worth noting, given the relatively clear conquest of Ireland, military and subsequently legal, that occurred in Davies' time. Dominating Irish debate throughout the eighteenth century, was the argument, following the lead of William Molyneux's The case of Ireland's being bound by Acts of Parliament in England stated (1698), that no conquest had ever taken place. ${ }^{130}$ To varying degrees, it was instead suggested that the native Irish had acquiesced or, more surprisingly, been almost wholly replaced by settler stock. ${ }^{131}$ The problems with patriot polemics are legion, perhaps none so much as the catholic character of much of the pre-1692 constitutional history claimed by protestant apologists. In the Abridgement, Burke argued that a conquest had occurred, though "it was indeed long before they were able entirely to subdue the island to the laws of England, the continual efforts of the Irish, for more than four hundred years, proved insufficient to dislodge them". ${ }^{132}$ He was, at the same time, critical of

127 Robert E Ward, John F Wrynn, SJ and Catherine Coogan Ward (eds), Letters of Charles O'Conor of Belanagare: a catholic voice in eighteenth-century Ireland (Washington, 1988), 131. See O'Conor's “A letter to David Hume, Esq, on some misrepresentations in his History of England", The Gentleman's Museum (April/May 1763) and David Berman, "David Hume on the 1641 Rebellion in Ireland", Studies 65 (1976) 101, esp 107-8.

128 Bisset, ii. 425-6.

129 WS i.479. See WS i.478-9.

130 See TO McLoughlin, Contesting Ireland: Irish voices against England in the eighteenth century (Dublin, 1999) and Anthony Carty, Was Ireland conquered?: international law and the Irish question (London, 1996).

131 See Andrew Carpenter (ed), The case of Ireland stated by William Molyneux (Dublin, 1977), 30-1.

132 WS i. 514. See generally WS i. 508-14. English involvement came about from native "faction and discontent" with Dermot McMurrough's call for English aid in a domestic dispute. Henry already had designs on Ireland and invaded, in part, as political penance for the murder of Thomas Beckett, in hopes of recovering the good graces of the English pope (Hadrian IV). Burke notes the irony that in "the submission of the Irish Chiefs to Richard IId mention by Sir John Davis", whatever its precise character, the Irish "bind themselves. . . to the Kings of England. . . supposing the Pope as the superior power. . (WS ix. 470)". Cf "On the right of settlements or conquered countries to be bound by the laws of the 
those, like Voltaire, who suggested that conquests were the preserve of civilised nations. ${ }^{133}$ More importantly, he was aware, as his writings on Ireland, America, and India make clear, of the negative effects and positive obligations of conquest and colonialism, on the "metropolitan" and conquered or settled country alike. ${ }^{134}$ But with its conquest a fait accompli, benefits could yet accrue to both Ireland and Britain. Burke sought, as Davies had claimed to, a union of manners, a deepening social commerce, and a more civil society between the two.

What is perhaps most remarkable about such a view is that the benefits of conquest are most evident in Burke's comments, not on Ireland, but on England. As with Irish patriotism, it remained an essential element of much English legal-political mythology that no Norman conquest had occurred. ${ }^{135}$ At the same time, the Normans were seen to corrupt the ancient laws of England, which even as late as Blackstone remained a rhetorical ideal. ${ }^{136}$ In Burke's English history and his fragment on the common law, he both acknowledged a Norman conquest and its civilising effect on the "rude and barbarous" Saxons, through the increased "communication" with the continent. $^{137}$ If they were not cannibals, the early English were a "people without learning, without arts, without industry, solely pleased and occupied with war, neglecting agriculture, abhorring cities, and seeking their livelihood only from pasturage and hunting". ${ }^{138}$ They were among the "most backward in Europe in all improvements, whether in military or in civil life". 139 Indeed, in his only clear criticism of the Norman William, it is easy to hear an Irish, rather than an 'English' voice, noting:

"To force against nature a new language upon a conquered people; to make them strangers in . . . courts of justice . . . ; to be reminded every time they had recourse to Government for

metropolitan or dominant country", WWM Bk P 27/46 (cites Davies) and see William Burke's "Notes on Ireland" in WWM Bk P 40.

133 See A note-book of Edmund Burke: poems, characters, essays and other sketches in the hands of Edmund and William Burke now printed for the first time in their entirety, HVF Somerset (ed) (Cambridge, 1957) 119.

134 He noted in his critiques of British policy in India that " $[\mathrm{t}] \mathrm{ime}$ has, by degrees, in other places and periods. . . blended and collated the conquered and the conquerors (WS ix. 614)". Cf. WS iii. 139-40 and see WS ix. 636-7 (on Quebec).

135 See Matthew Hale, "How the common law of England stood at and for some time after the coming of King William I" in A history of the common law ( $\left(2^{\text {nd }} \mathrm{edn}\right)$ London, 1716 [originally published posthumously in 1713]), esp. 107-8. Cf WS i. 322-3 (on Hale).

136 See the discussion in John Cairns, "Blackstone, an English institutist: legal literature and the rise of the nation state", (1984) Oxford J of Legal Studies 318, esp 354-60. See also JGA Pocock, The ancient constitution and the feudal law: a study of English historical thought in the seventeenth century (Cambridge, 1986 [A reissue with a retrospect]).

137 WS i. 430. Cf WS i. 330-1, i. 399. The phrase "rude and barbarous" was a trope long in use about the Irish. John Gillingham has noted its use in the twelfth century by William of Malmesbury, as well as by Spenser about the English past. "The English invasion of Ireland" in Brendan Bradshaw, Andrew Hadfield, and Willy Maley, Representing Ireland: literature and the origins of conflict, 15341660 (Cambridge, 1993). See Spenser, View, 67.

138 WS i. 429.

139 WS i. 428. 
protection of the slavery, in which it held them; this is one of those acts of superfluous tyranny, from which very few conquering nations or parties have forlorn, though no way necessary, but often prejudicial to their safety." 140

In the recurring debates over English exceptionalism and insularity, Burke's vision of English history and his criticisms of its jurisprudence and legal pedagogy remain too often overlooked. ${ }^{141}$ Davies' extensive use of civil and canon law in the Reports and elsewhere has led to a re-evaluation emphasising the breadth of his jurisprudential erudition. ${ }^{142}$ A similar revision of Burke jurisprudence remains to be done. ${ }^{143}$

\section{Reason, Principle, Sentiment And Interest}

The events of the early seventeenth century altered fundamentally the character of both Irish laws and culture. English jurisprudence in Ireland introduced legal and commercial languages in many ways hostile to native manners. The subsequent erosion of Gaelic tradition illustrated the power of both. Among jurists, it was long a humanist commonplace, at once descriptive and prescriptive, that laws were to be suited to a people. Davies had said as much, though in practice he sought to fit the Irish to English laws. Almost two centuries later, in a letter (1792) to his son Richard Burke, then agent for the Catholic Committee, the senior Burke wrote:

"Instead of prating about Protestant ascendancies, Protestant Parliaments ought, in my opinion, to think at last of becoming Patriot Parliaments.

The Legislature of Ireland, like all Legislatures, ought to frame its Laws to suit the people and the circumstances of the Country, and not any longer to make it their business to force the nature, the temper, and the inveterate habits of a Nation to a conformity to speculative systems concerning any kind of Laws. Ireland has an established Government, and a Religion legally established, which are to be preserved. It has a people who are to be preserved too, and to be led by reason, principle, sentiment, and interest to acquiesce in that Government."144

140 WS i. 472. Cf Blackstone, Commentaries on the laws of England (1765-9), iii. 317. See Fuchs 235.

141 On the general debate, see Kelley, "History, English law, and the renaissance", Past \& Present 65 (1974) 24 (reprinted in Kelley, History, law and the human sciences: medieval and renaissance perspectives (London, 1984)); the answer by Christopher Brooks and Kevin Sharpe, "Debate: history, English law, and the renaissance", Past \& Present 72 (1976) 133; and Kelley's rejoinder following at p 143.

142 Pawlisch, "Sir John Davies, the ancient constitution, and civil law", Historical Journal 23 (1980) 689 and "Sir John Davies' Law reports and the case of proxies", Irish Jurist (n s) 17 (1982) 368.

143 Both Davies and Burke have been portrayed as exemplars of the "common law mind". See esp Pocock, The ancient constitution, 32-41 (on the Reports), 59-63 (on the Discovery), and 243 (on Burke)

144 "Letter to Richard Burke", WS ix. 650. 
As he wrote this, the British administration, informed by the analyses of the Burkes, were slowly forcing changes on the protestant "ascendancy" and removing the few remaining elements of the penal laws. In seeking closer ties between Britain and Ireland, against his "patriot" associates, Burke sought to make Davies' rhetoric reality. But the union for which he hoped was neither assimilation nor, I suspect, the ultimately compromised product of 1800 , three years after his death. It was finally, not a matter for the laws, and only partly of commerce, but essentially a question of manners. Burke sought not, as had Davies, to make the Irish "become English", but instead, by the contribution of all of Ireland, to enlarge the meaning of "British". 